\title{
Exploring the Role of Madrasah Service Learning in Enhancing Capability and Promoting Human Development in Banten
}

\author{
Naf'an Tarihoran \\ The State Islamic University Sultan Maulana Hasanuddin Banten, Indonesia \\ nafan.tarihoran@uinbanten.ac.id
}

\begin{abstract}
Islamic education institutions (IEIs) and particularly Madrasahs are increasingly being linked to debates about development. This perspective is dominated by two schools of thought. On the one hand, madrasahs are positioned as drivers of individuals' and societies' moral development. On the other hand, apart from an education focus, there is an emerging discourse that calls upon madrasahs to advance broader human development. The study is premised on two arguments. First, the overemphasis on moral imperatives of madrasah undermines and neglects their social values related to human development. Second, in the scholarly works focusing on madrasahs and human development, more work focusing on specific and concrete strategies that can enable madrasah to promote such notions of development is needed. This study builds on and contributes to the madrasah and human development debate by arguing that madrasah service learning (MSL) has great potential and some challenges to enable madrasah to promote human development. The study is situated within the qualitative approach, in which qualitative methods are employed to explore the perspectives of teachers, students and community members on MSL. The study collected qualitative data using document analysis, in-depth interviews, survey and observations. With qualitative analysis, I argue that MSL can enhance capabilities and promote human development values.
\end{abstract}

Keywords: Capability, human development, madrasah service learning.

\section{INTRODUCTION}

Indonesia is the most populous Muslim country in the world with over 200 million Muslims. With more than 50,000 Islamic schools in the country, the religious teachings in these schools have a direct and long-lasting impact on the Islamic orientation and lives of Muslims in the country and elsewhere [1]. Indonesia is also a home to the largest Islamic education system in the world where thousands of madrasahs exclusively cater to the educational needs of children from Muslim community [2].

Madrasahs are product of social and political decisions, but they also create and shape the future generation of leader. It is commonly believed that education plays the most significant role in the development of a nation Education may be regarded as an investment in human capital formation that lays the foundation for future economic growth and development of a country [3]. The madrasah education system is an important component of the Indonesian educational system, and became fully integrated into the national education system (Law 20/2003). It is therefore instructive to critically examine the educational pedagogy and service learning of madrasahs in Indonesia.

The role of Indonesia's madrasah system is unique in the Muslim world [2], for several reasons. First, the majority of the country's madrasahs are in the non-state sector, in most cases teaching Arabic religious texts alongside a non-religious curriculum. Madrasahs belong to centralized bureaucracies, associated with Indonesia's two leading Muslim organizations, Muhammadiyah and Nahdlatul Ulama [4]. Second, Indonesia's fragmented geography means that the availability of alternatives to madrasahs may vary across regions.

On the other hand, the desire to incorporate service learning into education is growing exponentially across the globe. Teachers in madrasah improve their delivery of knowledge and skills and become enlivened by the high level of student engagement that integrated service learning provides [5]. Students of madrasah make the essential connection that bring forth the best they have offer and help them create meaningful, relevant experiences. In other words, service learning is truly a win-win for all involve.

Madrasah service learning may respond to specific community needs or concern or to promote involvement with social issues. Many madrasahs in Banten see the direct link between service learning and civic responsibility, literacy, social and emotional development, and improved schools culture and climate. Madrasahs are also responding to schools or district requirements for incorporating service learning into curriculum and teaching method, and to maximize the benefits for all involved [6]. In other words, the above features of the country's education sector present a rich institutional context for studying madrasah service learning, and research on madrasah choice in Indonesia is limited.

In this paper, researcher uses some of the common explanations for madrasah service learning, using data from a data EMIS 2016, which contains information on student's enrolment status by madrasah types. Therefore, allows the researcher to empirically investigate the determinants of madrasah in Banten with focus on teachers, students, administrator, parents and community characteristics.

\section{Study Context}

Madrasahs offer the national core curriculum developed by the Ministry of Education and Culture (MOEC), and additionally teach religious subjects developed by the Ministry of Religious Affair (MORA). Students take the national examinations and can transfer into MOEC general schools. 


\begin{tabular}{lllllll}
\hline & Districts & A & B & C & D & Sum \\
\hline 1 & Kab Pandeglang & 185 & 173 & 197 & 84 & 639 \\
2 & Kab. Lebak & 139 & 224 & 225 & 77 & 665 \\
3 & Kab Tangerang & 260 & 294 & 197 & 68 & 819 \\
4 & Kab Serang & 158 & 122 & 187 & 79 & 546 \\
5 & Kota Tangerang & 357 & 105 & 58 & 24 & 544 \\
6 & Kota Cilegon & 62 & 13 & 41 & 22 & 138 \\
7 & Kota Serang & 65 & 19 & 56 & 24 & 164 \\
8 & Kota Tangsel & 99 & 86 & 44 & 18 & 247 \\
\hline
\end{tabular}

\begin{tabular}{lllll}
\hline Sum & 1325 & 1036 & 1005 & 396
\end{tabular}

Table 1. Madrasah in Banten: Raudhatul Atfal, Madrasah Ibtidaiyah, Madrasah Tsnawiyah and Madrasah Aliyah

Note:

A = RA-Raudhatul Atfal

$\mathrm{B}=$ MI-Madrasah Iftidaiyah

$\mathrm{C}=$ MTs- Madrasah Tsnawiyah

$\mathrm{D}=$ MA-Madrasah Aliyah

In $2016 / 17$, approximately 9,525 million students were enrolled in madrasah representing approximately $13 \%$ of the total student enrollment in Indonesia [7].

The MORA is responsible for three types of Islamic institutions. The most numerous are the 77,336 madrasah providing six years of primary education (Madrasah Ibtidayah or MI), three years of junior secondary education (Madrasah Tsanawiyah or MTs), and three years of senior secondary education [8].

\section{METHOD}

Given the vast number and diversity of madrasahs in Banten, it is impossible for this article to give a detailed discussion of all the Islamic schools such as Raudhatul Atfal and Madrasah Diniyah. Instead, this article aims to provide a broad overview of the service learning Madrasahs, identify some common trends in service learning and highlight some examples. The research data on Banten are obtained from literature review, document analysis, and survey conducted in February 2018 with 30 state-madrasahs in Banten by choosing purposively.

\begin{tabular}{ll}
\hline Scale $(\%)$ & Category \\
\hline $0-<25$ & Very Irrelevant (VIR) \\
$25-<50$ & Irrelevant (IR) \\
$50-<75$ & Relevant (R) \\
$75-100$ & Very Relevant (VR) \\
\hline Table 2. Category of the relevance level
\end{tabular}

Analysis of MSL elements using Likert Scale with four checklist options, namely: very not accordance, not accordance, accordance, and very accordance. The results of the documents are analyzed qualitatively and used to describe their relevance. To calculate and analyze it then the data transformed into quantitative data in accordance with the score are: 1, 2, 3, and 4. After the data are transformed into quantitative data, the calculation of the rating scale is by using the percentage. To determine the relevance level, use the category with the scale in Table 2.

\section{RESULT}

Human Resources of madrasah consists of teachers, students, administrators, parents, and the community around the school. Service learning in madrasah combines learning objectives with community service in order to provide a pragmatic, progressive learning experience while meeting societal needs. This Service learning involves students in service projects to apply classroom learning for local agencies that exist to effect positive change in the Banten community.

Based on interviewed with madrasah principles and documentation analysis, researcher found that they were three types of madrasah service Learning, namely direct service, indirect service and advocacy. More details will be elaborated as follows: a) Direct service, students of madrasahs are in direct contact with the people or agency they are helping. These activities include tutoring, visiting the elderly, da'wah, serving food to the homeless, and providing childcare during school community functions. b) Indirect Service, students of madrasah participate in activities that will help people. They do not work directly with the people. Activities include charity, fundraisers (Sadaqah), community clean ups, construction work, and collections. c) Advocacy, students do not participate in the actual job itself. The focus is to persuade people to do something by writing letters, speaking to groups, and performing. For example, students might write letters to the government to change a law or make a presentation on how to stop school violence.

In general, the smallest percentage is in the appropriateness of the MSL with the indicator of $54 \%$ (R), while the highest percentage is the conformity of the MSL, which is $96.05 \%$ (category VR). Some of small's percentage are Islamic entrepreneurship and Boarding schools activities for students at Madrasah Ibtidaiyah.

In service learning, madrasahs emphasize the following elements of service learning for several reasons. First, madrasahs service learning provides meaningful ways for students, teacher, administrators and community agencies to move together with deliberate thought and action.

\begin{tabular}{lllllllll}
\hline & A & B & C & D & E & F & G & H \\
\hline MI & 54.76 & 90.48 & 60.71 & 86.90 & 54.76 & 58.33 & 89.29 & 67.86 \\
MTs & 75.83 & 67.50 & 65.83 & 66.67 & 89.17 & 88.33 & 70.83 & 73.33 \\
MA & 96.05 & 61.84 & 72.37 & 69.74 & 90.79 & 88.16 & 76.32 & 72.37 \\
\hline
\end{tabular}

Table 3. Conformity of Madrasah Service Learnings

Note:

$\begin{array}{ll}\mathrm{A}=\text { Boarding } & \mathrm{E}=\text { Entrepreneurship } \\ \mathrm{B}=\text { BTQ } & \mathrm{F}=\text { Leadership } \\ \mathrm{C}=\text { Da'wah } & \mathrm{G}=\text { Calligraphy } \\ \mathrm{D}=\text { Tahfiz } & \mathrm{H}=\text { Marawis }\end{array}$


Second, students benefit academically, socially and emotionally, develop skills, explore numerous career options, and may come to appreciate the value of civic responsibility and actively participating in their community.

Third, teachers will make madrasah and education more relevant for their students collaborative with their colleagues and community partners to develop existing curriculum, and may find themselves professionally reenergized. Fourth, madrasah administrator may observe a boost in staff and students' morale as desired academic outcomes are archived, and madrasah profile is raised in community. Fifth, parents find new avenues for conversation with their children, and may help support service leaning within the madrasah and create family service experiences. Sixth, community partners received much needed help and may find themselves learning from the students as they teach or interact with them.

\section{CONCLUSION}

Madrasahs are considered as an important instrument for promoting economic growth and human development of the country. They play a vital role in building human capabilities and accelerates economic growth through knowledge, skills and creative strength of society. The madrasahs are not only important for the national economy, but individuals also benefit from it. It is natural to assume that opportunities for employment increase in accordance with the level of education a person holds. Similarly, the level of income is likely to correspond to a certain degree with the level of education. The entire community benefits by encouraging its students' thoughtful civic involvement and participation.

The beauty of madrasah service learning is that something real and concrete occurs. Teaching and learning process takes on new ideas and multiple dimensions. When the students engage intellectually and emotionally with a topic, they can light up with a revelation or connect two previously separate ideas. What the students have learned in madrasah suddenly matters and engages their minds and hearts. On the other hand, teachers and administrators also frequently respond enthusiastically to service learning, finding their students' eagerness and curiosity invigorating. In other words, education becomes relevant, as classroom extends to larger community.

For Banten province, where growth is essential if the continent is to climb out of poverty, education is very important factor. For last several years, Banten province puts greater emphasis on madrasah Ibtidaiyah and, more recently, madrasah Tsanawiyah and Aliyah.
There exists a connection between madrasah and human development. When madrasahs have service learning activities, objectives are not only linked to real community needs, but also that are designed in cooperation with community partners and service recipients. Thus, it can be concluded that the role of madrasah service learning in enhancing capability and promoting human development in Banten as well as in Indonesia is relevance.

\section{REFERENCES}

[1] Charlene, Tan, Educative Tradition and Islamic Schools in Indonesia Journal of Arabic and Islamic Studies,14 2014: 47-62 Nanyang Technological University, Singapore.

[2] Asadullah, M. Niaz, Madrasah for girls and private school for boys? The determinants of school type choice in rural and urban Indonesia. International Journal of Educational Development 62, 2018, 96-111. Retrieved on April $1, \quad 2018 \quad$ from: https://doi.org/10.1016/j.ijedudev.2018.02.006

[3] Mariana, Iatagan, Consequences of the Investment in Education as Regards Human Capital, 2nd Global Conference on Business, Economics, management and tourism, 30-31 October 2014, Prague, Czech Republic, retrieved on May 2018 from: https://www.sciencedirect.com/science/article/pii/S22125 67115004268

[4] Hasan, N., The salafi madrasahs of Indonesia. In: Noor, Farish A., Sikand, Yoginder, van Bruinessen, Martin (Eds.), The Madrasah in Asia, Political Activism and Transnational Linkages. Amsterdam University Press. 2008.

[5] Kaye, C. B., The complete guide to service learning: Proven, practical ways to engage students in civic responsibility, academic curriculum, \& social action. Free Spirit Publishing, 2004.

[6] Choiri, Moh Miftachul, Pemberdayaan Madrasah dan Pendidikan Berbasis Masyarakat, Jurnal Tarbiyah, Vol. 21, No. 2, July-December 2014

[7] Education and Management Information System (EMIS), Ministry of Religious Affair, 2017, retrieved on March 2018 from http://emispendis.kemenag.go.id/emis2016v1/

[8] Islamic Education (PENDIS) Ministry of Religious Affair, (MORA), 2017, retried on March 20, 2018 from https://pendis.kemenag.go.id/ 